\title{
Agon-Related Publications by the Author
}

\section{Books}

Siemens, H.W., / Roodt, V. (eds.) (2008a): Nietzsche, Power and Politics. Rethinking Nietzsche's Legacy for Political Thought. Berlin / New York: de Gruyter.

Siemens, H.W. / Pearson, J.S. (eds.) (2019): Conflict and Contest in Nietzsche's Philosophy. New York and London: Bloomsbury.

\section{Chapters/Articles}

Siemens, H.W. (1998): “Nietzsche's Hammer: Philosophy, Destruction, or The Art of Limited Warfare". In: Tijdschrift voor Filosofie 60/2, 321-347.

Siemens, H.W. (2001a): “Nietzsche's Agon with Ressentiment: Towards a Therapeutic Reading of Critical Transvaluation”. In: Continental Philosophy Review (formerly Man \& World) 34/1, $69-93$.

Siemens, H.W. (2001b): "Agonal Configurations in the Unzeitgemässe Betrachtungen: Identity, Mimesis and the Übertragung of cultures in Nietzsche's early thought”. In: Nietzsche-Studien 30, $80-106$.

Siemens, H.W. (2001c): “Nietzsche's Political Philosophy. A Review of Recent Literature”. In: Nietzsche-Studien 30, 509-526.

Siemens, H.W. (2002): "Agonal Communities of Taste: Law and Community in Nietzsche's Philosophy of Transvaluation". In: Journal of Nietzsche Studies 24 Special Issue on Nietzsche and the Agon, 83-112. (reprinted in: Francis Mootz III / Peter Goodrich (eds.): Nietzsche and Law, (Series: Philosophers and the Law). Aldershot, Ashgate, 309-338.)

Siemens, H.W. (2005): “Action, Performance and Freedom in Hannah Arendt and Fr. Nietzsche”. In International Studies in Philosophy 37:3, 107-126.

Siemens, H.W. (2006): “Nietzsche contra Liberalism on Freedom”. In: Keith Ansell-Pearson (ed.): A Companion to Nietzsche. Oxford and Malden MA: Basil Blackwell, 437-454.

Siemens, H.W. (2007): "The first Transvaluation of all Values: Nietzsche's Agon with Socrates in The Birth of Tragedy". In: Gudrun von Tevenar (ed.): Nietzsche and Ethics. Bern: Peter Lang, 171-196.

Siemens, H.W. (2008b): “Nietzsche's equivocations on the relation between democracy and 'grosse Politik"'. In: Herman W. Siemens / Vasti Roodt (ed.s): Nietzsche, Power and Politics. Rethinking Nietzsche's Legacy for Political Thought. Berlin / New York: de Gruyter, 231-268.

Siemens, H.W., (2008c): "Nietzsche and the Temporality of self-Legislation". In: Manuel Dries (ed.): Nietzsche on Time and History. Berlin / New York: de Gruyter, 191-210.

Siemens, H.W. (2009a): "(Self-)legislation, Life and Love in Nietzsche's Philosophy". In Isabelle Wienand (ed.): Neue Beiträge zu Nietzsches Moral-, Politik- und Kulturphilosophie. Fribourg: Press Academic Fribourg, 67-90.

Siemens, H.W. (2009b): “Nietzsche's Critique of Democracy”. In: Journal of Nietzsche Studies 38, Fall 2009, 20-37.

Siemens, H.W. (2009c): “Umwertung: Nietzsche's 'war-praxis' and the problem of Yes-Saying and No-Saying in Ecce Homo". In: Nietzsche-Studien 38, pp.182-206.

Siemens, H.W. (2009d) : Review of D. Conway: Nietzsche and the Political. In: Journal of Nietzsche Studies, 36, 207-216. 
Siemens, H.W. (2012a): "The Rise of Political Agonism and its Relation to Deconstruction". In: A. Martinengo (ed.): Beyond Deconstruction: Rethinking Myth, Reconstructing Reason. Berlin / New York: de Gruyter, 213-223.

Siemens, H. W. (2012b): “Nietzsche's 'post-Nietzschean' political 'Wirkung': The Rise of Agonistic Democratic Theory". In: Renate Reschke / Marco Brusotti (eds.) : "Einige werden posthum geboren": Friedrich Nietzsches Wirkungen. Berlin / New York: de Gruyter, 393-406.

Siemens, H. W. (2013): "Reassessing Radical Democratic Theory in the light of Nietzsche's Ontology of Conflict”. In: Keith Ansell-Pearson (ed.): Nietzsche and Political Thought. London: Bloomsbury, 83-106.

Siemens, H. W. (2014): “Nietzsche's Concept of 'Necessity'and its Relation to Laws of Nature”. In: Vanessa Lemm (ed.): Nietzsche and The Becoming of Life. New York: Fordham University Press, 82-102.

Siemens, H. W. (2015a): "Nietzsche's Socio-Physiology of the Self”. In: Joao Constâncio / Maria Joao Branco / Bartholomew Ryan (eds. ): Nietzsche and the Problem of Subjectivity. Berlin / New York: de Gruyter, 629-653.

Siemens, H.W. (2015b): "Nietzsche sobre el conflicto y el Pluralismo de los Ordenes Legales" (Nietzsche On Conflict and the Pluralism of Legal Orders). In: Estudios Nietzsche 15, Special Issue on Nietzsche and Politics, 113-125.

Siemens, H.W. (2015c): “Agonal Writing: Towards an Agonal Model for Critical Transvaluation”. In: Logoi.ph - Journal of Philosophy 1/3 - Playing and Thinking, 1-29.

Siemens, H.W. (2015d): “Nietzsche's Philosophy of Hatred”. In: Tijdschrift voor Filosofie 77/4, Special Issue on Anger \& Hatred, 747-784.

Siemens, H.W. (2015e): “Contesting Nietzsche's Agon. On Christa Davis Acampora’s 'Contesting Nietzsche'. Discussion paper”. In: Nietzsche-Studien 44, 446-461.

Siemens, H.W. (2016a): "Nietzsches Sozio-Physiologie des Selbst und das Problem der Souveräntität”. In: Helmut Heit / Sigridur Thorgeirsdottir (eds.): Nietzsche: Denker der Kritik und der Transformation. Berlin / New York: de Gruyter, 167-182.

Siemens, H.W.(2016b): "Nietzsche e a sociofisiologia do eu”. In: Cadernos Nietzsche 37/1, $185-218$.

Siemens, H.W. (2017): "Nietzsche contra Kant on Genius, Originality and Agonal Succession". In: Marco Brussotti / Herman Siemens / Joao Constancio / Tom Bailey (eds.): Nietzsche's Engagements with Kant and the Kantian Legacy, vol. III: Aesthetics, Anthropology and History, Maria Joao Branco / Katia Hay (eds.), 15-42.

Siemens, H.W. (2018a): “Nietzsche’s Agon”. In: Paul Katsafanas (ed.): The Nietzschean Mind (The Routledge Philosophy Minds series). New York / Oxford: Routledge, 314-333.

Siemens, H.W.(2018b): “Nietzsche's 'Agonale Betrachtungen': On the Actuality of the Greeks in the Unzeitgemässe Betrachtung”. In: Analisa Caputo (ed.): Rethinking the Nietzschean Concept of 'Untimely', Milan: Mimesis International, 23-39. 